\title{
Transport Practices in Amish Communities
}

James P. Warren ${ }^{1}$

Department of Engineering \& Innovation

The Open University, Walton Hall

United Kingdom

\author{
Marcus P. Enoch \\ Transport Studies Group \\ School of Civil and Building Engineering \\ Loughborough University \\ United Kingdom
}

\begin{abstract}
Car ownership is growing in many countries. While beneficial to individuals in many cases, this trend has often resulted in significant economic, social, and environmental costs to society more generally. In researching possible solutions, one approach is to look at particular areas or communities that exhibit less reliance on the car or are even 'car free' to some extent, in order to see if lessons can be learned. Accordingly, this study seeks to define and characterize transport practices in Amish communities - in groups located across the United States and Canada — which for religious reasons have eschewed the car. Specifically, the paper draws on a comprehensive literature and archival review, supplemented with expert interviews, to briefly outline Amish beliefs and traditions, and then relate how these influence people's mobility by mode, journey purpose, community, and stage of life. The study considers mobility by utilizing twelve broad mobilities as motivations, along with examples applied across six suggested stages of life. The twelve motivations considered are: migration; business / profession; discovery; medical related; military related; post-employment; trailing travel; travel across modes; travel for service work; tourist travel; visiting friends / relatives; and work / commuting. The six life stages are infancy, preschool, scholars, young people, adults, and old folks. The impacts of Amish transport are then considered with respect to society more broadly but also for each of the life stages.
\end{abstract}

\section{Keywords}

Amish; horse and buggy; environmental impacts; mobility; trip purposes; transport motivation

\section{Acknowledgements}

We are thankful to those at the Young Center for Anabaptist and Pietistic Studies, Elizabethtown College, who have been so helpful in locating articles and references, and providing time for interviews. We also thank the editors for their helpful comments and Jane Collinson for her support as librarian. Any mistakes or omissions are ours and should be forwarded for corrections. 


\section{Introduction}

Car ownership is growing nearly everywhere, but while beneficial to individuals in many cases, motorization has often resulted in significant economic, social, and environmental costs to society from accidents, pollution, congestion, and other external effects. In considering mobility solutions, one approach is to look at particular areas or communities that exhibit less reliance on the car or are even 'car free' to some extent, in order to build up a rich picture of that community and draw out lesson to be learned. This study attempts to define and characterize transport practices in broad mobility terms for Amish communities, which for religious reasons have eschewed the car.

\section{Framing Car Free / Car Reduced Communities}

In summarizing perhaps the key contributions to the car free communities research field, Scheurer (2001), Melia (2009), and Morris, et al. (2009) looked at car free / reduced developments mostly at the site level, while Crawford (2000) comprehensively reviewed car reduced / free examples at the city level. Warren and Enoch (2010) studied car reduced / free communities at the larger scale by focusing on specific island states. Previously, Cairns, HassKlau, and Goodwin (1998) reviewed a range of schemes that involved capacity reductions, mostly through physical mechanisms for a range of reasons and over a range of timescales, from small to medium sizes and from temporary to permanent. Finally, Enoch and Warren (2014) provided a ten-point framework which categorized car free communities according to

- level of 'car freeness;'

- spatial size;

- degree of permanence;

- whether they occur on a planned and regular basis, or whether they are a more reactive and / or irregular or 'one off' events;
- the motivations for establishment;

- the means by which they have been enforced;

- the 'type of boundary';

- the 'permeability' of the boundary;

- the roles of the different stakeholders involved; and

- the nature of the broader context.

Interestingly though, so far such studies have to focused on cases where physical, regulatory, or fiscal mechanisms are in place, and especially on examples that were imposed by authority agents on areas with clearly delineated geographical boundaries, hence the decision to investigate a community which for moral or religious / cultural reasons has decided within itself to remain car free, and which is culturally rather than geographically boundary circumscribed.

\section{Methodology}

The paper is based primarily on the results of a comprehensive literature and archival review of documents that were kindly made available by the Young Center for Anabaptist and Pietist Studies at Elizabethtown College in Pennsylvania. Specifically, it also draws on writings by Amish scribes and other authors through the Family Life publication of Aylmer, Ontario, 
Pathway Publishers. Olshan (1988) describes Family Life as the most general of Amish publications; the content includes various topics. The overall mission is "the promotion of Christian living with special emphasis on the appreciation of our heritage” (Olshan 1988, 146, as quoted from Wagler, 1968. “What is Family Life?” Family Life, January).

Methods and modes of travel by community along with reasons for travel were extracted from 30 specific examples from Family Life, taken from Scott's archive using his own index system. Key words from the topic index included terms such as death, migration, accidentsbuggy, travel, tourism, tractors, machinery, and horses and buggies. The index does not aim to be inclusive but is selective in that key articles are indexed based on the Young Center's needs. There are certainly many more non-indexed articles that refer to travel and transport in Family Life. However, indexed Family Life articles still represented an instrumental sample to consider, spanning from 1968 to 2007. We did not choose from approximately another 15 to 20 categories that included farm accidents, working life, hobbies, technology, splitting, etc. While many did mention trips within their articles and would be worthy of further analysis, our primary goal was to apply the mobilities to a small sample set to check the methodology. Igou (1999) compiled writings of the Amish using sixteen headings by broad topics such as life, working life, marriage, old age, etc. There is no index in that volume; however, we have tried to extract mobilities and attitudes towards mobility whenever possible, citing the original source when known.

These findings were then supplemented by exploratory, semi-structured, in-depth interviews, a technique which allows significant flexibility in following up interesting areas of study but which allows some control to be maintained (Drever 1995). Specifically, these were conducted with two Amish scholars, Donald Kraybill and the late Stephen Scott, both recognized experts, i.e., individuals with specialized knowledge in a specific field with demonstrated experience and involvement which is of particular interest to a specific study (Gläser and Laudel 2004). The results were subsequently analyzed using a form of thematic analysis, which is widely used in qualitative studies (Denzin and Lincoln 2000).

The paper firstly considers the implications for transport practices by providing evidence of travel patterns among the Amish and the broader societal impacts, before reporting the implications for policy and practice elsewhere. Each of the twelve mobilties is described with examples. This study explicitly refers to the Amish as those who take claim to that name (Kraybill 2010) and also conform to five major signifying tenets of faith or markers of identity such as the use of: horse and buggy travel, specific clothing, Pennsylvania German (or a Swiss German dialect), lack of grid electricity within the household, and attending their own schools, usually one-room schools (Kraybill and Nolt 2004). The study refers to those who are not Amish, as 'English,' following the convention of others (Kraybill, Johnson-Weiner, and Nolt 2013). 


\section{Table 1: A Typology of Mobilities and Their Descriptors}

\begin{tabular}{|c|c|c|}
\hline Type & Name & Mobilities with examples of some possible core motivations \\
\hline M1 & migration & $\begin{array}{l}\text { Migration from cultural home to new land / country, homeless travel, being } \\
\text { a refugee, seeking asylum }\end{array}$ \\
\hline M2 & business & $\begin{array}{l}\text { Travel for business or for professional reasons (includes shopping for food, } \\
\text { supplies, and other household items) }\end{array}$ \\
\hline M3 & discovery & $\begin{array}{l}\text { Discovery travel such as gap years, ancestral heritage, and potentially } \\
\text { educational visits (museums, etc.) }\end{array}$ \\
\hline M4 & medical & Travel related to getting medical attention \\
\hline M5 & military $(*)$ & Military travel or mobility related to the armed services \\
\hline M6 & post-employment & $\begin{array}{l}\text { Post-employment travel including travel for leisure, vacations, holiday } \\
\text { periods, or visiting distance communities }\end{array}$ \\
\hline M7 & trailing & $\begin{array}{l}\text { Trailing travel of children, partners, or relatives (includes church } \\
\text { attendance)—also called escort trips }\end{array}$ \\
\hline M8 & diaspora travel $(*)$ & $\begin{array}{l}\text { Travel and migration across the key nodes within a given diaspora, such as } \\
\text { that of overseas Chinese }\end{array}$ \\
\hline M9 & service $(*)$ & Travel of service workers, especially to global cities \\
\hline M10 & tourist & $\begin{array}{l}\text { Tourist travel to places and events, especially through the tourist gaze- } \\
\text { also known as leisure travel }\end{array}$ \\
\hline M11 & V.F.R. & $\begin{array}{l}\text { Travel linked to visiting friends and relatives including when those } \\
\text { networks might be on the move -a form of leisure travel }\end{array}$ \\
\hline M12 & Work & Work related travel including commuting (includes education linked travel) \\
\hline
\end{tabular}

\section{Mobility Patterns and Typology}

In this section twelve broad types of mobility, as described by Urry (2007), have been applied to Old Order Amish (O.O.A.) stories of travels and trips. These mobilities have been drawn largely from the literature and for each typology an attempt is made to exemplify and demonstrate the mode as existing. These patterns of movement are important as they define mobility throughout the human lifecycle and also interaction with technology and the English. A key question for the study is to consider which mobilities are utilized or permitted, and to illuminate areas where mobilities are distinctly different when contrasting Amish and English, just as one may consider Amish transport systems and impact a potential form of carfree communities or places. Thus the broad forms of mobility are summarized in Table 1.

\section{Migration (M1)}

The Amish and their living history accentuate the story of mobility through their migration from Europe to the New World. The story is particularly evident from the stories within the Martyr's Mirror which emphasizes the struggle for religious freedom explained in Unser Leit (Beachy 2011). One might refer to this as the "great migration" partly as it is 
described as a mass exodus during the 1700s where one does not return or have present day connections (which exist in M8). As the European Amish eventually died out, this phase has closed. However, there exists a narrative of subsequent migrations within the O.O.A. whereby communities splinter off and go elsewhere to start new communities. The reasons why O.O.A. splinter off are well known and include shunning progress (Hostetler 1964), due to technological or broader social developments. In some cases these new communities also fail (Luthy 2007) due to various issues, categorized as nine key factors, or some combination thereof. Thus, in 2007, approximately 111 settlements had become extinct over 1961 to 2007, across 26 states, Canada (Ontario and British Vancouver), Honduras, and Paraguay. Hostetler (1964) adds that "migration ...is one of the most important factors in resisting acculturation" (197) and makes clear that migration acts as a possible pathway away from threats linked with progress. This migration can lead to further travel, attempting to link newly established communities with previous locations, like visiting relatives as described in M11 (visiting friends and relatives). Family Life articles which encapsulated migration mobilities included those describing the migration to the Belize settlement. Here bus travel was used in and around Central America. Other articles described family histories that extended back to 1535 (Switzerland) and 1766 to 1769 (Germany), connecting present with past lives and mobilities. These family histories represent living mobility over and through time and offer a way for descendants to relate to their ancestors and their journeys, sometimes often citing oppression from others.

\section{Business (M2)}

Mobilities linked to profession and earning at first seems contradictory. However, like other Amish riddles (Kraybill and Nolt 2004), once examined, makes sense. Mobilities derived from professional or business travel include areas of work requiring rural to urban mobility. Journeys include the delivery of people and their produce to farmers' markets, such as Philadelphia, Reading, and Baltimore (Scott 2011). For example, a survey of 35 large Amish enterprises showed that 20 used some form of vehicle services for accessing mobility as part of their business (Kraybill and Nolt 2004). Kraybill and Nolt (2004) make the distinction that ethnic enterprises rely on external materials and expertise outside Amish households. Glick $(1994,93)$ recalls how cattle, produce, milk, and butter were all shipped by railroad freight cars during the early 1900s and how Amish life was then dominated by the importance of the rail system with respect to getting goods to and from market.

We hypothesize that mobility levels probably rise for businesses which are either integrated or hybrid since they rely on a higher proportion of external resources, such as products made, customers served, suppliers used, and technologies employed (Kraybill and Nolt 2004, 32). Enterprise type also dictates the mobility level expected for each of the four broad establishment types, namely sidelines, cottage industries, manufacturing establishments, and construction crews, with mobility increasing across this spectrum (Kraybill 2011). Cottage industries and seasonal supplementary work-normally involving activity around the home and sales of food products, produce, crafts / craft items as sidelines, and smaller family based stores 
(Kraybill 2001, 39-40)—rely less on transportation outside the household. These enterprises sometimes require deliveries, but probably do not normally require mobility for the labor force, or certainly less than larger enterprises. One such example includes visiting a prospective English client in order to explain details, provide a quote, or complete a sale, which would be dependent on being on site. Meanwhile barn, shed, silo, fitted cabinetry, and gazebo construction is typically off-site, but in some cases may require a visit to ensure measurements are correct. Mobile crews will have higher mobility levels in order to reach construction sites. They may also have greater access to technological tools like lifting equipment, nail guns, and other electrical tools not typically permitted by their church district. Scott (2011, L.54) also notes the shift from dairy farming to other sometimes more mobile working patterns:

...And what to do with that land? Dairy farming is not as profitable as it used to be. And, oh, there are different alternatives to dairy farming. Produce farming seems to be a little more profitable. The Amish have created sort of co-ops and produce auctions where the Amish and older Mennonites come to an auction house with their produce there, with fruits and vegetables and even flowers and other things. And buyers come in from even Philadelphia and elsewhere, from grocery store chains or whatever. And they would buy the fruits and vegetables through the auction. That's something the Amish have started just in the last decade or so.

\section{Discovery (M3)}

Mobilities linked to discovery and exploring refers to any trips undertaken by students, au pairs, and, more generally, young people to gain overseas experience (Urry 2007). Urry considers this a rite of passage, which normally involves going overseas to civilization centers. At first, one would not normally connect Amish with this practice. Yet, there are instances where travel is sanctioned, for example, in order to appreciate and see first-hand the birth places of the Anabaptist practices as described in Unser Leit (V1:217). The chapter recounts the story of a lone Amishman, J.B. Fisher, who in 1908, and again in 1953 to 1954, visited many historic sites associated with the martyrdom in Europe. Another example of this historic pilgrimage is recounted by Hostetler (1993, 50-65). Historic pilgrimage trips continue to this day and are normally organized as guided groups over a two week period and can be costly (Anonymous 2013). Scott (2011, L.318) said, "Well, one destination of a lot of wild Amish youth has been sort of an Amish resort, ... in Florida [Pinecraft]...It's mostly retired people that go down there for the winter and wild youth." Other discovery mobilities in Family Life include the places visited by conscientious objectors and historical narratives about the Pennsylvania Turnpike.

\section{Medical (M4)}

Travel for health includes all travel linked to hospitals, dentists, opticians, and spas. One finds evidence of these trips both within Family Life and other Amish authored books and articles. There is nothing particularly special with respect to this trip motivation, except that 
Amish probably travel less for medical treatment due to taking care of themselves whenever possible (Igou 1999). However, the rules of the Ordnung can be relaxed when emergency medical treatment is required, in these cases an airlift trip via helicopter. In other cases, travel by scheduled flight, a form of aeromobility, may be permitted to undergo surgery at specialist hospitals usually after consulting with the church. Butterfield (1997), is his book, describes his long period as a driver for Amish families living in Holmes County, Ohio, taking many medical related trips. Trip motivations include: getting females to the local birthing center when the baby is due (13), visiting poorly relatives in the hospital (19) and regular health screening tests (31).

\section{Military (M5)}

Mobility related to military (M5) travel includes movements of armed service workers and all other types of equipment (tanks, planes, rockets, etc.). Initially, this mobility domain was not expected to apply to Amish since Amish are not involved in armed services due to their stance on non-violence and non-confrontation (Igou 1999, 315-342). However, Wagler (1993) reports instances during World War II when Amish were drafted and, because they were registered as conscientious objectors, worked in Civilian Public Service camps from 1941 to 1945, as told in Family Life. Examples of such travel existed during other conflicts (i.e. World War I, the Korean War, and the Vietnam War) when Amish undertook alternative service as conscientious objectors. Fisher (1978), in chapter 30, describes life for Lancaster Amish boys serving as conscientious objectors near Boonsboro, MD, mending fences and doing copious hard labor. The labor shortage due to the war meant that many nearby towns were continually recruiting Amish boys to work. The war carried with it a theme of rationing and thrift, and this theme is expressed when authors write about this mobility.

Butterfield's (1997) passenger recounts a story of his son, at age 18, who "went for alternative service as a hospital orderly during Vietnam War” (1997). From the passage, based on the hourly pay rate, nearly 2,000 hours of service were supplied, perhaps over one and a half to three years. All service people had to get to their point of work, either on a regular or occasional basis, generating trips much in the way of service workers (M9). Other works about C.P.S. experiences are available but not reviewed.

\section{Post-Employment (M6)}

Mobility in this category is any travel that occurs during retirement. In the case of some Europeans this is transnational, when retirees own properties abroad like seaside cottages or second homes. However, for retired Amish this could include leisure trips (holidays, day-trips) or visiting settlements to see friends and relatives. This mobility has a similar motivation to that described in M11. In some cases, post-retirement travel may be discovery travel, especially if linked to heritage travel as noted in Beachy's (2011) story of Fisher. Other destinations are national parks or places of beauty, as Scott (2011, L.368) says:

...more controversial yet, well-to-do Amish who will hire a driver with a motor home to 
take them on a leisure trip, a vacation trip to, say, Yellowstone Park or tourist places. That's taught against and probably in some formal Ordnung, that's spelled out, that you don't do that. But in some ways, it certainly does happen.

\section{Trailing (M7)}

Trailing travel (also known as escort travel) by spouses is evidenced in Amish communities directly after marriage, as when the newly married wife moves into the husband's community, which can be some distance away. Trailing travel also applies to children who follow parents and / or other relatives like elder parents following children. Although not specifically noted by Urry (2007), in an Amish context, this would also likely include mobilities associated with religious events like church attendance. Trailing travel may also occur if parents move onto their children's property, or vice-versa, after an employment change. One example is when parents occupy a smaller house (dawdy house) adjacent to the main home of the son or daughter. This mobility is linked to post-retirement travel (M6) in some circumstances.

In Family Life, trailing travel is discussed with respect to rider and driver etiquette in taking trips and also in historical contexts during rail trips, walking arduous trips to reach Sunday church or to get back home after such sojourns.

\section{Diaspora (M8)}

Diaspora (M8) is highlighted by many Amish authors and others writing about the Amish. Cohen (2008) describes the Mennonite diasporas as arising from internal schisms in the sixteenth century, as the Christian Anabaptists formed and spread. This original diaspora is described in Unser Leit (Vol.1) within the chapters entitled "Oh! — But for a Home” and "Pennsylvania HO!" telling of the movement across Europe and then North America in the early 1700s. This story, or "ancestral migration," is recounted many times in Amish writings. However, here, ancestral migration is placed within the migration (M1) category which also includes asylum; thus M8 in this study is not included as a singular category.

\section{Service (M9)}

The travel and mobilities of service workers around the world, especially to cities, to provide any type of work or services to others is the core definition of M9. Service related mobility in this study does not include military related mobility but does include the movement of workers such as domestic servants and au-pairs kept within a form of contemporary slavery in which Bales (1999, quoted in Urry 2007, 11) refers to as a disposable people. While it might be expected that this form of mobility does not apply to the Amish, Glick (1994, 81-82) recounts the travel story of seasonal tomato picking, which drew in workers, Amish youth workers, from nearby Millwood, Maple Grove, and Weavertown churches, in Pennsylvania. Others came to Pennsylvania to help with seasonal agriculture from as far away as Iowa and Kansas. This mobility was not explicitly observed in Family Life; however, references to it were made in 
Amish Enterprise (Kraybill and Nolt 2004) with respect to construction workers providing mobile services. Scott (2011, L.434) also noted this when discussing the need for van drivers who support the movement of Amish goods for sale in markets.

... another frequent use for van drivers and that's to take Amish to the so-called farmer's markets in cities. Like, the Reading Terminal market in Philadelphia, markets in Baltimore. I don't think any local Amish go to New York City but there probably still are a number of Amish people who are transported into New York City itself.

The authors feel that service work, in the Amish case, represents a sub-set of travel which is more akin to professional mobility, rather than that of providing 'contemporary' servitude.

\section{Tourist (M10)}

Tourist mobility and travel tourism to visit places and events, and any mobilities in relationship to various senses like the "tourist gaze"-which one might normally associate with English gazing on the Amish (Chhabra 2009; Trollinger 2012)—is denoted by M10. Although the existence of the "English gaze" is well-established, there is also evidence for the Amish participating in the tourist gaze. One noted area is the Sarasota / Pinecraft, Florida settlement, established in the late 1920s (Stevick 2007). National parks are also sightseeing destinations. Amish normally travel these distances by bus or Amtrak, treating the outing as an excursion. Youth may also travel in personal cars or hitch a ride with friends to get to Florida. In the case of the Pinecraft, Stevick estimates that at peak season some two thousand visitors weekly "squeeze into all available rooms" in about one square mile. One interesting parallel here is that the distances covered are sometimes surprising to those who do not know about Pinecraft. There is much evidence for this mobility, but we suggest that it is not as high as that for the non-Amish. We also include mobility linked to leisure within this category such as trips linked to fishing, sport (softball, volleyball, etc), hunting, or other activities. Golf-related mobility would also feature here, but it was ended by decree in 1997 (Kraybill 2001). Again Scott noted (2011, L.L.204-206) that as job patterns changed so has mobility over time.

...if you have like a woodworking business, you're not tied down as much to milk the cows at a certain time every day. And you're not tied down by the seasonal agricultural work so you have more time to do more recreational type activities. It's a big change and a lot of Amish people would say it's not for the best to have so much leisure time and there would be some very successful businessmen who might even go golfing, that sort of thing. ... I've never seen it but I've heard of it.

\section{Visiting (M11)}

Visiting friends and relatives (M11, and also abbreviated here as V.F.R.) represents a large number of trips for many. V.F.R. has been affected by networks on the move (Urry 2007), as with electronic device-based connectivity like telephony (mobile phones and smart phones) 
and other web-enabled portable devices. The Amish demonstrate some of these mobilities through frolics, sisters' days, buddy groups, singings, reunions, picnics, auctions, and generally visiting or socializing (Kraybill 2001, 150-153). In many cases, these are special days whereby very early morning departure times are required to maximize leisure time, especially if the destination is far. Landing (1972) found that for a settlement of just over 2,000 people nearly all social visiting type trips were undertaken by automobile with either a loaned, rented, or hired basis. He concurred that these trips, and thus interconnections, are a strong function of similarity in lifestyles, intermarriages, strong kinship bonds, as well as the needs for social visiting. His study noted Nappanee Amish had no trips to or from Tennessee, Arkansas, and Virginia due to the lack of the above factors. Scott (2011) also noted that there is sometimes a tension in Amish writing focusing on overuse of the automobile versus the acceptable use of automobiles. This is sometimes expressed as becoming too dependent on using drivers (Anonymous 2007). Scott used the terms "sparingly" and not "using [taxi] drivers promiscuously” when trying to describe these tensions. Visiting mobilities are frequently mentioned in Family Life, as with trips during C.P.S., hauling Amish, rail trips, long distance bus trips, manners of drivers (of cars and buggies) and passengers in hired cars, and becoming overly dependent on using drivers.

\section{Work (M12)}

The work travel (M12) segment includes areas of work which require mobility including mobile crews for construction (Kraybill and Nolt 2004, 81), as well as walking, bicycling, or taking a scooter. Mobile work could include landscaping, masonry, roofing, painting, house framing, outbuilding erection and general contractor work accounting for about $10 \%$ of overall activity. Visits to auctions may also play a role here too, however, this study places them elsewhere as those trips seem to combine both work and play aspects (Kraybill 2001). This study also includes school related trips, as a young scholar's employment is as a student.

The shift towards factory work necessitates commuting on a regular basis when Amish work for or with the English. Commuting is met by diverse modes including work vans (Englishowned and operated), hired or rented motor vehicles, or in limited cases animal traction if close to home (Landing 1972). Land use patterns are also important (Scott 2011). There is friction at Amish settlement boundaries and this friction can be manifested in transport activity. This friction is noted in Table 2, including etiquette and reliability of van drivers and expected behavior / etiquette of Amish passengers. In some districts, church districts moderate these mobility practices to some extent. As Olshan (1988) says, "there is no single, formally organised group known as the Old Order Amish,” (158), and thus our work highlights that mobility practices need "to encompass all the diverse and autonomous churches within this terminology."

\section{Travel Patterns within the Amish Community}

In Table 2, mobilities were assigned using Urry’s typology of twelve mobilities along with more standard trip motivations. Trip surveys normally ask respondents to state the main trip 
purpose, perhaps from one of ten choices (N.T.S. 2011). ${ }^{2}$ However, Urry’s mobilities frequently include many smaller trips, such as those in typical trip purpose surveys. Thus, the two sets of descriptors are not necessarily fully compatible. One would expect, for example, that migration (M1) would include many sub-trips or multiple linked trips such medical travel M4) or trailing travel (M7). In that sense the broad mobilities are not mutually exclusive and can be complimentary in some cases. Table 2 chronologically summarizes trip motivations observed in Family Life articles, along with key themes. Other themes emerged that do not fit well with trip purpose or conventional transport categories and are summarized after the 12 mobilities.

\section{Table 2: Mobilities Themes in a Sample of Family Life Articles}

\begin{tabular}{|c|c|c|}
\hline Article Date & Themes Observed & Mobilities \\
\hline Feb. 1968, 14-15, 20 & $\begin{array}{l}\text { Uses the metaphor of horse \& buggy to describe the importance } \\
\text { of morality standards }\end{array}$ & \\
\hline Apr. 1968, 25-26, PtII & Settlement in Belize; travel is very different in British Honduras & M1, M10 \\
\hline Apr. 1972,25-27 & Day trip via train (Nappanee to Chicago) ends in tragedy (1865) & M10 \\
\hline Jan. 1974, 10-13 & $\begin{array}{l}\text { Migration by train, MO to IN, reconnoiter mission, walks } 60 \\
\text { miles to get home (1865); Lancaster, PA, walking to church } \\
\text { (1803, no buggies); six hour walk to church in Montbeliard } \\
\text { (Switzerland, 1700s); walking as different forms. }\end{array}$ & $\begin{array}{l}\text { M1, M7, } \\
\text { M10 }\end{array}$ \\
\hline Aug. 1975, 23-24 & $\begin{array}{l}\text { Work related (agricultural sector) travel to purchase machinery; } \\
\text { dealers travelling up to } 800 \text { miles to get machinery (1970) }\end{array}$ & M12, M2 \\
\hline Aug. 1975, 24 & Health of horses & M11, M12 \\
\hline Feb. 1981, 26-27 & $\begin{array}{l}\text { Mobility increases with the use of tractors; larger scales of } \\
\text { business, complexity and debt, call for simplicity }\end{array}$ & M12, M2 \\
\hline Apr. 1985, 24 & Van rider etiquette & $\begin{array}{l}\text { M7, M10, } \\
\text { M12, M11 }\end{array}$ \\
\hline May 1986, 9-11 & $\begin{array}{l}\text { Misuse and/or overuse of cars; alcohol and buggies don’t mix; } \\
\text { taking a stand against alcohol like automobiles }\end{array}$ & \\
\hline Oct. 1986, 37- end & Hauling Amish; tobacco and cancer (death) & M7, M11 \\
\hline Feb. 1989, 19-22 & $\begin{array}{l}\text { Male, aged 23, hit by car, evening, died next day (1948), friend } \\
\text { escaped uninjured (mourning and funeral traditions) }\end{array}$ & \\
\hline Feb. 1989, 27 & Diesel engines, noise safety, health / hearing & M4 \\
\hline Jul. 1990, 26-27 & Work time vs. family time; tourism gaze; moderation in all things & M2, M10 \\
\hline Jan. 1991, 19-22 & $\begin{array}{l}\text { Moderation in commercialism; questions the value of the tourist } \\
\text { gaze. }\end{array}$ & $\begin{array}{l}\text { M10 leads } \\
\text { to M12/M2 }\end{array}$ \\
\hline Feb. 1991, 12-17 & $\begin{array}{l}\text { Driver safety and education for horse and buggy users; safety, } \\
\text { courtesy, and rules }\end{array}$ & M2 \\
\hline May 1992, 5-6 & Accidents (death) and practicing Christian values in driving & \\
\hline
\end{tabular}




\begin{tabular}{|c|c|c|}
\hline Feb. 1993, 31-34 & Stationed in CPS (1942 to 1946), visiting many places, travelling & $\begin{array}{l}\text { M3, M5, } \\
\text { M11 }\end{array}$ \\
\hline Mar. 1993, 17-19 & $\begin{array}{l}\text { Turnpike history (1795); visits to farms; connections to } \\
\text { Philadelphia }\end{array}$ & M3, M11 \\
\hline Jan. 1994, 20-23 & $\begin{array}{l}\text { Draw of the tourist gaze to the lost past, slower way of life, } \\
\text { mystique status }\end{array}$ & \\
\hline Oct. 1995, 17-19 & $\begin{array}{l}\text { Family history; tragic deaths: horseback (1768), buggy and truck } \\
\text { (1941), child hit by truck who survives but eventually dies (1991) }\end{array}$ & M2 \\
\hline Dec. 1995, 31-32 & $\begin{array}{l}\text { Car seats, use, and the law, travelling and safety. One family who } \\
\text { gave up van hire and switched to public transport. }\end{array}$ & M2 \\
\hline May 1996, 18-21 & $\begin{array}{l}\text { Family history (Switzerland, 1535); tragic deaths in automobile } \\
\text { accidents, usually as passengers (1925; 1965). Comment on } \\
\text { Beachy Amish-Mennonites allowing auto ownership (1942). }\end{array}$ & $\begin{array}{l}\text { M1, M4, } \\
\text { M2 }\end{array}$ \\
\hline Dec. 1996, 20-23 & $\begin{array}{l}\text { New settlements that failed (1961 to 1996) and using Greyhound } \\
\text { bus for travel (hazards, 1963); La Grange, IN, to Wallacetown, } \\
\text { ON (1962). }\end{array}$ & M1, M11 \\
\hline Dec. 1996, 31 & Using drivers and being considerate & M2, M12 \\
\hline May 1997, 9-12 & $\begin{array}{l}\text { Travelling on bus, issues and barriers; reasons for using the bus; } \\
\text { train travel pros and cons }\end{array}$ & $\begin{array}{l}\text { M11, M3, } \\
\text { M10 }\end{array}$ \\
\hline Jun. 1997, 28-31 & $\begin{array}{l}\text { Accidents in buggies; controlling horses; teaching drivers } \\
\text { adequately and by example; accidents on farm equipment (1956), } \\
\text { lessons learned }\end{array}$ & M2 \\
\hline Jun. 1998, 34 & How to buy a good work horse (animal welfare) & \\
\hline Nov. $1998,19-22$ & $\begin{array}{l}\text { Family history (Germany, 1766, 1769); tragic death (1890); trip } \\
\text { to Kansas; buggy maker / designer (Timkin bearings, 1951); } \\
\text { buggy road tests; being fined for no license plates in LaGrange } \\
\text { County, IN (1954) }\end{array}$ & M1, M12 \\
\hline Apr. 2005, 10-12 & Manners when using taxis / drivers and experiences as a driver & $\begin{array}{l}\text { M11, M12, } \\
\text { M2, M4 }\end{array}$ \\
\hline Oct. 2007, 15-18 & $\begin{array}{l}\text { Using drivers for short trips (shopping); dilemmas in becoming } \\
\text { too dependent on using drivers too often }\end{array}$ & $\begin{array}{l}\text { M2, M4, } \\
\text { M11 }\end{array}$ \\
\hline
\end{tabular}

Family Life references like "February, 1991 pages 12-17” are shortened to "Feb., 1991, 12-17.” Full article information is given in an appendix.

Specific mobility observations totaled 49, with the most common three being: business related travel (M2, 12 citations), visiting friends / relatives (M11, nine citations), and tourism related trips (M10, seven citations). As expected, trips linked to service workers (M9) and the general diaspora (M8) were not noted. Although it was thought that travel linked to military service (M5) would not feature, it did in one article. Perhaps surprisingly there was no specific mention about post-employment leisure trips (M6), although such trips may have been linked to V.F.R. Education, commuting, medical, and migration stories were noted in at least four to six articles, followed with lesser instances of discovery and trailing travel. Themes which did not match trip motivations or specific mobilities included animal health; accidents and / or lessons 
learned from accidents; tragedy / death linked to transport; safety; alcohol use; car misuse; car overuse; and morality, moderation, and values applied to travel related situations. In a similar survey of Family Life, Olshan (1998) finds a tension of being in the world but not of it:

The truth of the matter is the Amish are not physically separated from the rest of the world. In fact, even the largest Amish settlements are located in counties where the Amish are a small minority. Passing automobiles and airplanes, electric lines, junk mail, salespeople, customers, employers, doctors, bankers, and an array of inspectors and other government officials are all a daily part of Amish life. Because contact with the world is constant, separation from the world is achieved only through constant struggle (156).

Mobility patterns as a function of life stage were also considered briefly using the above trips and further examples taken from narratives in books. Hostetler and Huntington (1971) apportions Amish life into periods such as infancy, preschool, scholars, young people, adults, and old folks, and these periods map onto various mobilities, and thus trips throughout a personal life. These trips are described in detail throughout historic stories from Amish writers such as Fisher (1978), Glick (1994), and Stevick (2007). Qualitatively there is an emphasis on trips linked to recreational activities and education for scholars (see especially Glick) although workrelated transport stories are also commonly recalled. In Fisher and Glick, there are more than 20 to 50 examples of transport related incidents or stories within the narratives. Fisher indeed has devoted an entire chapter (pages 257 to 268) to transportation and service, which spans from the 1860s to recently. That book has a strong emphasis on employment, particularly agricultural related work, but industries linked to milk, fruit, and vegetable sales also are discussed.

Movement of workers for seasonal produce picking are highlighted, along with other services (the fire fighting appliances, buses, and some train lines) are described, both by Fisher and Glick. We hypothesize that mobility as an overall trend increases throughout life, perhaps either peaking in young people or adults, although this is difficult to quantify. In some cases, stories of Amish authors / historians, or those who spent a "life of travel" due to connections with C.P.S., or for ancestral heritage trips, may have increasing levels of mobility far into older ages. Visiting friends and relatives and remote settlements also appears as a common theme in most examples cited here and would tend to increase overall mobility.

\section{Implications for Practice and Policy Elsewhere}

One question raised is: what key factors regulate Amish mobility? Although a definitive answer would be difficult to formulate, we offer some potentially important factors that drive mobility of all people, including "Amish transport.” It also invites a question about how does Amish mobility compares to "sustainable transport" visions and non-Amish Pennsylvanian statistics. We suspect that Amish mobility is much lower than that for English. Vonk $(2011,91)$ has estimated some values for two Lancaster families, finding large differences based on whether the family business was accruing substantial miles or not. In one case, the family business had a motorized mobility about $45 \%$ higher than the average U.S. family. Conversely another Amish 
family recorded 2,400 miles per year, which is about one-sixth the national average. Clearly more work is required to collect and analyze such figures for a variety of households in a settlement. Overall we expect the majority of Amish to accrue less annual mobility when compared to their neighbors.

Our work has highlighted examples of how Amish culture regulates Amish mobility through various means, as with community or collective agreements. This parallels some European car-free communities. Although individuals may be motivated to reduce mobility, collective groups can be a catalyst. Some of the main factors which regulate Amish mobility include: household income, household size, ages of those in the household, main occupation type of the household head, settlement size, Ordnung strength, proximity to a major urban center, as well as cultural surroundings. Certainly with higher weekly working hours and / or higher physical activity levels, overall mobility is lower in motorized forms, especially for those based primarily at home (Vonk 2011, 94). With much time dedicated to work or household related chores, less time is left for travel. Also, with respect to horse and buggy transport, speeds are much lower — eight to ten M.P.H._-and maximum distances are lower-20 miles, followed by a rest (Vonk 2011) — which ought to result in lower, and different, mobilities for the Amish.

Among the Amish, specific rules and taboos "admonish[es] people not to use taxi drivers promiscuously” (Scott 2011). Scott recalls further controversy surrounding a story about a family hiring a motor home (and driver) to take the family on a leisure trip to Yellowstone Park and elsewhere. These examples show the reflexive nature of Amish decision making and the tensions it may cause (Kraybill, Johnson-Weiner, and Nolt 2013). Core motivations towards mobility or abstaining from mobility can be generically grouped into broad categories. These core motivations or beliefs can change overall mobility patterns significantly. Anable (2005) showed clear distinctions of car users where the environmental concern was a core theme. Others (Poortinga, Steg, and Vlek 2004) quantified the importance of spirituality and religion with respect to environmental behavior. That work observed that spirituality / religion equated with quality of life as being the fifth most important factor, along with identity / self respect and security for a large sample of the population of the Netherlands. Both types of core motivations can appear equally forceful in modifying behaviors and even coexist.

\section{Concluding Remarks}

This paper sought to define and characterize transport practices in Amish communities and explore how Amish mobilities differ from the English. Other groups which merit further attention include groups that take a vow of poverty and abstain from transport. These may include Buddhists, as Ariyesako (1999) states that "traveling in a vehicle in the Buddha's time was an extravagance. A strict application of this training in Thailand is not allowing bhikkhus to drive or own vehicles, and (officially) not to ride on motorcycles.” A study of Buddhist monks in Sri Lanka, who provided relief after the tsunami in 2004, also offers evidence of negotiated outcomes. Crosby (2008) writes: 
The constant assessment of monks' negotiated involvement in worldly matters usually revolves around more everyday matters. Monks are often deeply sensitive to this issue and related tensions: some monks who drove vehicles in order to collect bodies after the tsunami were fulfilling their welfare roles, and in particular their association with the proper treatment of the dead, yet found themselves criticised for driving (an activity conventionally prohibited for Theravada monks) and expressed their distress at this... The line between compassion and over-involvement, while inconsistent, can also be quite rigid” (56).

Similar tensions are felt and observed for transport practices with the Amish. Like the Buddhists, there seems to be a spectrum of restriction which is influenced by the local conditions and expectations.

Another group of interest could be both genders in Saudi Arabia (Sunni Islamists) and their respective mobility practices; currently there is a ban for females, based on a religious edict, as opposed to a specific traffic law, that forbids females from driving (Internations 2013). However, like all practices, some report that it is being slowly changed over time (McDowell 2013) but there is still complexity in practice. Driving on the Sabbat (the Sabbath) is forbidden, as are many other practices, for Jewish people (Chabad 2014). Yet, this group has many ingenious ways of observing their faith and maintaining shomer shabbat (shabbat observant). Other linkages to mobility include Sabbat laws that forbid telephone use and turning on or off anything which uses electricity, including lights, radios, television, computer, air-conditioners, and alarm clocks. Doing laundry, going shopping, and making business transactions are all also not permitted on the Sabbat. Thus, it seems there are probably more examples where mobility is regulated in a reflexive way than one might first expect.

This study attempts to consider how future 'hypomobility' (or lower mobility) lifestyles might be achieved through more deeply considering how, why, and where other groups like the Amish undertake travel and movement, especially with emphases on animal traction and human powered modes. One similarity between horse-and-buggy Amish and English groups wanting to reduce their own car use seems to be the notion that a conscious decision making process is involved and that in some cases this is framed as a type of continuous cycle which evolves over time and results in negogiated outcomes. The entire decision process is influenced by multiple external factors for both groups even though the core motivation may be quite different.

\section{Endnotes}

${ }^{1}$ Contact information: James P. Warren, Department of Engineering \& Innovation, The Open University, Walton Hall, Milton Keynes, MK7 6AA, UK; +44 (0) 1908659554 james.warren@open.ac.uk

${ }^{2}$ These ten basic choices are: commuting, business, other work, education, shopping, personal business, social or entertainment, holidays / daytrips, just walking, and escort trips. 


\section{References}

Anable Jillian. 2005. “Complacent Car Addicts or Aspiring Environmentalists?: Identifying Travel Behaviour Segments Using Attitude Theory.” Transport Policy 12:65-78.

Ariyesako, Bhikkhu. 1999. “The Bhikkhus' Rules A Guide for Laypeople. FAQ 12: Are monks allowed to own and/or drive vehicles? Is this allowed by the Vinaya? If it does not go against the Vinaya, would it still be socially acceptable, given the monk's spiritual status in society?" Retrieved 28 February 2014 (http://www.accesstoinsight.org/lib/authors/ariyesako/layguide.html\#faq).

Beachy, Leroy. 2011. Unser Leit. Millersburg, OH: Goodly Heritage Books.

Butterfield, Jim. 1997. Driving the Amish. Scottdale, PA: Herald Press.

Cairns, Sally, Carmen Hass-Klau, and Phil Goodwin. 1998. Traffic Impact of Highway Capacity Reductions London: Landor Publishing.

Chabad. 2014. "The Shabbat Laws.” Retrieved 28 February 2014 (http://www.chabad.org/library/article_cdo/aid/95907/jewish/The-Shabbat-Laws.htm).

Chhabra, Deepak. 2009. "How They See Us: Perceived Effects of Tourist Gaze on the Old Order Amish. Journal of Travel Research 49(1):93-105.

Cohen, Robin. 2008. Global Diasporas. Abington, UK: Routledge.

Crawford, J. H. 2000. Car Free Cities. Utrecht, Netherlands: International Books.

Crosby, Kate. 2008. "Kamma, Social Collapse, or Geophysics? Interpretations of Suffering among Sri Lankan Buddhists in the Immediate Aftermath of the 2004 Asian Tsunami.” Contemporary Buddhism 9(1):53-76.

Denzin, Norman K., and Yvonne S. Lincoln. 2000. Handbook of Qualitative Research. London: Sage Publications.

Drever, Eric. 1995. Using Semi-Structured Interviews in Small-Scale Research: A Teacher's Guide. Edinburgh, United Kingdom: Scottish Council for Research in Education.

Enoch, Marcus P. and James P. Warren. 2014. “Categorising Carfree Communities.” Urban Design and Planning: Proceedings of the Institution of Civil Engineers 167(1):42-43.

Gläser, Jochen, and Grit Laudel. 2004. Expert Interviews and Qualitative Analysis. Wiesbaden, Germany: VS Verlag für Sozialwissenschafen.

Glick, Aaron S. 1994. The Fortunate Years: An Amish Life. Intercourse, PA: Good Books. 
Hostetler, John A. 1964. "Persistence and Change Patterns in Amish Society.” Ethnology 3(2):185-198.

Hostetler, John A. and Gertrude E. Huntingdon. 1971. Children in Amish Society: Socialization and Community Education. Holt, Rinehart and Winston Press.

Hostetler, John A. 1993. Amish Society. Baltimore, MD: John Hopkins University Press.

Igou, Brad 1999. The Amish in Their Own Words: Amish Writings from 25 years of the Family Life Magazine. Scottdale, PA: Herald Press.

Internations. 2013. Driving in Saudi Arabia, Retrieved 28 February 2014 (http://www.internations.org/saudi-arabia-expats/guide/driving-in-saudi-arabia-16101).

Kraybill, Donald B. 2001. The Riddle of Amish Culture. Baltimore, MD: John Hopkins University Press.

Kraybill, Donald B. and Steven M. Nolt. 2004. Amish Enterprise: From Plows to Profits. Baltimore, MD: John Hopkins University Press.

Kraybill, Donald B. 2010. Concise Encyclopedia of Amish, Brethren, Hutterites, and Mennonites. Baltimore, MD: John Hopkins University Press.

Kraybill, Donald B., Karen M. Johnson-Weiner and Steven M. Nolt. 2013. The Amish. Baltimore, MD: John Hopkins University Press.

Landing, James E. 1972. “The Amish, the Automobile, and Social Interaction.” Journal of Geography 71(1):52-57.

Luthy, David. 1991. "The Origin and Growth of Amish Tourism in Holmes County, Ohio.” Family Life January:19-22.

Luthy, David. 1996. "Why Some Amish Communities Fail: Extinct Settlements, 1961-1996.” Family Life December:20-23.

Luthy, David. 2007. Why Some Amish Communities Fail: Extinct Settlements, 1961-2007. Aylmer, ON: Pathway Publishers.

McDowall, Angus 2013. "Saudi Women Driving Ban Not Part of Sharia-Morality Police Chief.” Reuters News 19 September. Retrieved 28 February 2014 (http://in.reuters .com/article/2013/09/19/saudi-women-driving-idINDEE98I0CO20130919).

Melia, Steve. 2009. The Potential of Car Free Development in the U.K. Doctoral dissertation. Bristol, UK: University of the West of England. 
Morris, David., Marcus P. Enoch, David E. Pitfield, and Stephen G. Ison. 2009. "Car-Free Development through U.K. Community Travel Plans.” Urban Design and Planning: Proceedings of the Institution of Civil Engineers 162(DP1):19-27.

National Transport Survey 2011. “Notes and Definitions.” U.K. Department for Transport. Retrieved 28 February 2014 (https:/www.gov.uk/government/uploads/system/ uploads/attachment_data/file/49693/nts2011-notes.pdf).

Olshan, Marc. 1988. “Family Life: An Old Order Amish Manifesto.” Pp. 143-160 in The Religion and Family Connection: Social Science Perspectives. edited by D.L. Thomas. Provo, UT: Brigham Young University Religious Studies Center.

Poortinga, Wouter, Linda Steg, and Charles Vlek. 2004. "Values, Environmental Concern, and Environmental Behavior: A Study into Household Energy Use. Environment and Behaviour 36(1):70-93.

Scheurer, Jan. 2001. Urban Ecology, Innovations in Housing Policy and the Future of Cities: Towards Sustainability in Neighbourhood Communities. Doctoral dissertation. Western Australia: Murdoch University.

Stevick, Richard A. 2007. Growing up Amish: The Teenage Years. Baltimore, MD: John Hopkins University Press.

Trollinger, Susan L. 2012. Selling the Amish: The Tourism of Nostalgia. Baltimore, MD: The Johns Hopkins University Press.

Urry, John. 2007. Mobilities, Cambridge, U.K.: Polity Press.

Vonk, Martine. 2011. Sustainability and Quality of Life: A Study on the Religious Worldviews, Values, and Environmental Impact of Amish, Hutterite, Franciscan, and Benedictine Communities. Amsterdam: Buijten \& Schipperheijn.

Warren, James P., and Marcus P. Enoch. 2010. "Island Transport, Car Ownership, and Use: A Focus on Practices in Cuba, Malta, Mauritius, and Singapore.” Island Studies Journal 5:193-216. Retrieved 28 February 2014 (http://www.islandstudies.ca/ sites/islandstudies.ca/ files/ISJ-5-2-2010-Warren+Enoch_0.pdf). 


\section{Appendix 1: Primary Sources}

Anonymous. 1972. “A Tragic Train Death-1901.” Family Life April:15-17.

Anonymous. 1975. “Heaves.” Family Life August/September.:24.

Anonymous. 1981. “The Changing Times.” Family Life Februrary:26-27.

Anonymous. 1985. “Dear Van Riders.” Family Life April-June:24.

Anonymous. 1986. “A Word from the Taxi Man.” Family Life October:37-back cover.

Anonymous. 1989. “Diesels-A Hearing Hazard.” Family Life February:27.

Anonymous. 1990. “The Problem Corner—The Tourist Trade.” Family Life July:26-27.

Anonymous. 1991. "Driving Safely with a Horse and Buggy (sections 1 to 13).” Family Life February:12-17.

Anonymous. 1992. "Staff Notes: Buggy Accidents.” Family Life May:5-6.

Anonymous. 1995. “The Problem Corner—Child Seatbelt Laws and Car Seats.” Family Life December:31-32.

Anonymous. 1996. “It’s Been on My Mind—Using Drivers.” Family Life December:31.

Anonymous. 1997. “Travelling by Bus.” Family Life May:9-12.

Anonymous. 1997. “Must Accidents Happen?” Family Life June:28-31. Sections 14 to 18, various contributors.

Anonymous. 2005. “Overheard in the Back Seat.” Family Life April:10-12.

Anonymous. 2007. “The Driver Who Failed the Test.” Family Life October:15-17.

Anonymous. 2013. Personal communication from an Old Order Amish person with author. June 8.

Fisher, Gideon L. 1975. "History of Horse-drawn Machinery.” Family Life August/September:23-24.

Fisher, Gideon L. 1978. Farm Life and Its Changes. Gordonville, PA: Pequea Publishers.

Kraybill, Donald B. 2011. Personal communication. December 19.

Luthy, David. 1989. "Black-Bordered Handkerchiefs: A Nearly Extinct Funeral Custom.” Family Life February:19-22. 
Luthy, David. 1993. “A Turnpike Traveler in 1854 Views an Amish School.” Family Life March:17-19.

Luthy, David. 1994. “Marketing the Amish.” Family Life January:20-23.

Luthy, David. 1995. “Fisher Family History.” Family Life October:17-19.

Luthy, David. 1996. “Hershberger Family History.” Family Life May:18-21.

Luthy, David. 1998. “Schrock Family History”. Family Life November:19-22.

Miller, J.L. 1998. “Buying a Good Workhorse.” Family Life June:34

Scott, Stephen. 2011. Interview session at Young Center with author. Transcript. December 19. (L. refers to line number in transcript).

Stoll, Elmo, and David Wagler. 1968. “Bus Loads to British Honduras.” Family Life April:2526.

Stoll, Elmo. 1986. “Alcohol and Buggies.” Family Life May:9-11.

Stoll, Joseph. 1974. “Let’s Go for a Walk.” Family Life January:10-13.

Wagler, David. 1968. “Horse and Buggy Morals.” Family Life February:14-15, 20.

Wagler, David. 1993. “The World Is Big.” Family Life February:31-34. 